\title{
Software Projects Success by Objectives
}

\author{
Eman, Yassien \\ WISE University, Software Engineering Department, Jordan \\ E-mail: eman.yassien@wise.edu.jo
}

\author{
Received: Oct. 28, $2017 \quad$ Accepted: Dec. 11, $2017 \quad$ Published: January 1, 2018 \\ doi:10.5296/jmr.v10i1.10149 \\ URL: https://doi.org/10.5296/jmr.v10i1.10149
}

\begin{abstract}
Evaluating project success in the changing environment of software industry is critical to organizational success. The main issue is projects' diversity in various domains, thus a variable development criteria for each project's success is essential. This paper proposes new model Success by using the Objectives (SbyO) model based on project objectives, stakeholders' priorities, and the project time frame. The SbyO model contribution consists of four components; first, the model evaluates projects success through the degree they achieve their stipulated objective; second, the model considers the importance (or the value) of stakeholders' perspectives in setting the priority of what perspective to consider and what other perspectives to ignore; third, the model takes into account the timeframe for executing the elements of the specified criteria; finally, the model provides SbyO cross-table to the organizations for the practical implementation the model. The SbyO was evaluated by two experts; results show applicability in software systems.
\end{abstract}

Keywords: Project success, Project management, Software, Information System, Measure 


\section{Introduction}

There are many examples where projects technically were successful however they failed to achieve stakeholder objectives. The Advantix project was recognized by PMI as the international project of the year 1997 because this project meets the traditional criteria (On time, within budget and to specification), but the project failed to achieve its strategic goals because Kodak could not detect the rapid growth of digital photography and as a result of this, the company stock price dropped down 67\% (Cuthbertson et al., 2015). The F-20 aircraft project was completed according to the same traditional iron triangle, but recorded as another failed project when no single aircraft was sold (Howsawi \& Eager, 2014). Also Google Lively, Google Answers, Dodgeball and Google Buzz are names of failed SW projects that were initiated earlier by Google and cost Google millions of dollars, even though they were stopped regardless of their traditional success measure (Time, cost and scope) status, and were discontinued due to the lack of users interest or because they did not live up to the company's strategies and expectations (Mlot, 2013). All the above stories are clear examples of the deficiency of the traditional criteria in measuring success. The provision of a clear, an unambiguous and an accurate definition of project success criteria is critical to provide information that may help in processes of making effective decision, identifying critical success/failure factors and implementing successful projects. It also improves IS outcome and creates better utilization for project resources (Dalcher, 2014; Bhoola, 2015). In literature there is two main streams of project success; one of them handles the determinants of success and failure such as critical success factors (Ika, 2009; Mishra, et al, 2011; Law and Ngai, 2007; Kamhawi, 2007; Nelson, 2007; Bhoola, 2015), while the other, works on project success measures (Ika, 2009; Thomas \& Fernandez, 2008). The author chooses to dig in the second stream due to its importance in setting the stage for the first stream (determinants of success), as it is a perquisite for identifying the success and failure factors. Literature needs to set a good generally accepted criterion in order to identify acceptable critical success factors. Agreeing upon the definition of project success criteria is considered a real problem in literature (Ika, 2009). Several views are presented, but the most dominant one in project management community is the problem of objective view that is also widely spread in practical life as well. (Agrawal \& Rathod, 2006; Ika, 2009). Due to this partial and narrow view of project success, there have been many calls in literature to present new contributions to this area. (Alderman \& Ivory, 2011; Ika, 2009). Although it is essential to set the basis for project success measures, it is not acceptable to use the same measure for different projects that carry different objectives, different customers, different business nature and different circumstances in a rapidly changing environment. Some projects target nonprofit goals, others target innovation with lower consideration to efficiency and higher consideration to effectiveness, and others seek for image enhancement. Social responsibility projects for example have very unique success criteria than business projects. Nilsson (2009) identifies one type of social responsibility investors among three others, whose main concern is social responsibility over financial return. SW projects also generally have more complexity and uniqueness than others with big variations in clients circumstances from business to business. Thus it is important to take into account projects diversity, by presenting different criteria per project. We propose a new model called Success by using the Objectives (SbyO) in order to help measure project success 
based on target objectives of relevant stakeholders. Not only the timeframe is important in our model but also the degree of objective importance and the priority to stakeholders. Moreover, the model, provides a guideline to measure project success. First, we discuss the software projects' diversity. Next, we list the related works to project success. Then we illustrate the proposed, and finally section 5 provides the conclusion. 2 Software Projects: Software (SW) industry is very customer oriented and its development depends highly on collecting requirements for each case (Handigund \& Arunakumari, 2013); whereas the final product (the software) changes for every customer and for every deliverable based on their needs and circumstances, that's why SW development is mainly accomplished via projects. (Wiener, 2006; Handigund, \& Arunakumari, 2013; Bhoola, 2015). A SW project is temporary endeavored with a start and an end dates that are undertaken to create a unique SW product to meet the project's objectives (PMI, 2013). Projects have better success rates when they are managed efficiently (Wiener, 2006; Ghapanchi, 2015; de Carvalho, Patah \& de Souza Bido, 2015) however, SW project management deals with the challenges of human- based development that SW development faces. Keeping in mind that “. . . today's major problems with software development are not technical problems, but management problems" (Brooks, 1987). Therefore, proper management of software projects has been proven to have crucial importance for success, (Ruhe \& Pfahl, 2015; Bhoola, 2015), as it is considered as a better resource optimization and effective way to reach goals and objectives. (Wiener, 2006; de Carvalho et al., 2015) But, unfortunately, it has been noticed that SW projects generally have lower rates of success compared to other industries (Chemuturi \& Cagley, 2010; Schwalbe, 2016). It is true that basic tools and techniques are the same for all projects, but the results differ when using them effectively, and SW industry unique characteristics must be considered. Two important issues cause the uniqueness of SW projects; the nature of the product (the SW product) and development technologies that are used to develop the SW (Ruhe \& Wohlin, 2014; Chemuturi \& Cagley, 2010). The final product (The Software) is intangible and abstract; (Weiner, 2006) it can't be physically touched, neither fully visualized nor described accurately especially at the first stages of the project. Moreover, SW products are considered complex (Weiner, 2006; Schwalbe, 2016), and that is what makes it more difficult to capture all required details at once, especially with low skilled employees. Requirements mostly are accumulated during project life time. This cause several problems related to gathering changing requirements which turns to implementing SW requirements as hunting a moving target. The nature of the instable requirements pushed SW Engineering society to use several process methodologies that consider requirement accumulation nature such as Agile Software Development Methodology. (Weiner, 2006; Chemuturi \& Cagley, 2010).

Furthermore, the other issue that characterizes SW projects is the used technology. Technologies used in SW development do not stand alone; they are lied in a full landscape (Adomavicius et al, 2008) and interact with the other components from the related ecosystem. Compatibility and following up with other technologies in the ecosystem such as the used operating system is essential for project success, which increase complexity of SW development. The situation becomes more complicated because these technologies change rapidly and faster than other construction technologies, which puts more pressure on project's 
members to learn and to keep up with new updates. (Weiner, 2006; Bhoola, 2015).Following up these changes causes technologies to outdate, quickly, before they even get mature enough to form a set of proven best practices. (Weiner, 2006). Finally, product abstraction, its complexity and the changing technology, all increase the degree of uncertainty in SW projects and decrease success probability. (Ruhe \& Wohlin, 2014) Concluding from what have been discussed above that, although main SW projects deliverables are the same for other projects (business deliverables, the product (Software) and the project management process deliverables), the following factors must be considered thoroughly when managing a SW project to ensure its success; adopted process methodology, resources, constraints and risk, as discussed below. 3 Software Projects Success Measures: Many authors introduced several definitions for SW project success (Barclay and OseiBryson, 2009; Thomas and Fernández, 2008; Agarwal and Rathod, 2006), and some others used empirical studies (Sauer et al., 2007; Mitchell, 2006; Jonkers et al, 2015; Howsawi \& Eager, 2014). However, Only minimum numbers of influencing papers are scattered among some journals during the last seven years. (Barclay and Osei-Bryson, 2009; Thomas and Fernández, 2008; Ika, 2009; Mcleod et al, 2012; Jonkers et al, 2015; Howsawi \& Eager, 2014). One reason for this rareness is the fact that both project management (McLeod, 2012) and Information technology are new fields. (Weiner, 2006; Schwalbe, 2016) The objective view is the most dominant perspective in literature since 1960s (Ika, 2009; Mcleod et al, 2012), and the most used in practical life (Agrawal \& Rathod, 2006; Ika, 2009). Objective views or as described by Baccarini (1999) the hard dimensions are featured by being measurable, while soft dimensions are subjective, and more difficult to be measured. (Ika, 2009).Project success has been described objectively in terms of the known golden triangle; completing project on time, within budget and to specification (Schwalbe, 2016; Pan et al. 2008). It specifically measures the project management process success (Ika, 2009; Schwalbe, 2016). On contrary, project management success represents an internal and only short-term perspective of a project, and not overall project success (Davis, 2013). Project success must include both internal and external, and short and long term perspectives as well (Joosten, Basten \& Mellis, 2011; Jonkers et al, 2015; Howsawi \& Eager, 2014) in order to be accurate to reflect the real picture of what's going on inside these operational entities, and what their effect on the long run is. On the first hand, the above mentioned objective definition is widely used due to the ease of its measurement (Mcleod, 2012) and because it is said that it measures projects operational efficiency success (Wang et al., 2006; Mitchell, 2006). It's also easily used for evaluating project manager performance. (Jugdev \& Moller, 2006). On the other hand, it has been criticized by several writers that it's too narrow and limited in scope (Baccarini,1999; Ika, 2009; Jonkers et al, 2015; Howsawi \& Eager, 2014) to capture the complex, multi-stakeholders and multifaceted nature of SW projects (Nelson, 2005) as it is described in the previous section.Moreover operational success does not always mean strategic success, especially when operational success is not aligned with organizational strategy; instead, it's considered a failure. The importance of different measures is realized (Ika, 2009; Jonkers et al, 2015; Howsawi \& Eager, 2014) and they also cause a great shift in literature to consider different criteria such as client satisfaction, strategic objective and business success. (Ika, 2009, Mcleod \& Macdonell, 2012; Ojiako et al., 2008; Erling, 2006) However, most of the authors agree upon considering project management process as one 
important dimension of the measure, but it isn't sufficient when it is handled alone. For example Baccarini (1999) defines project success in terms of two components; project management success, and product success, where he considers satisfaction of different stakeholder groups with regard to the project and its outcomes. Nethathe, Waveren and Chan (2011) define project success as both project success and project management success, where the project success is considered as achieving the set goals. Meanwhile Westhuizen and Fitzgerald (2005) also describe project success as a system consists of two components, and they also argue that success is based on project management success and project's product success. Westhuizen and Fitzgerald (2005) propose the idea of appening two elements to traditional standpoint of project success new elements- quality of project management process and satisfaction of stakeholders' needs. Pinto \& Slevin (1988) ensure the importance of project success over time and introduce an instrument for measuring project success. It consists of two main dimensions, the project and the client, each one of them is concerned with several factors; time, cost and performance which represent the project's dimensions, while the client's dimensions are represented in effectiveness and satisfaction. Nelson (2005) argues that project success must be seen through the eyes of different stakeholders and that project success must be seen as process and outcome success. He considers product as part of the process in a similar way to what Pinto \& Slevin (1988) did, but he adds learning to the outcome as shown in the figure.

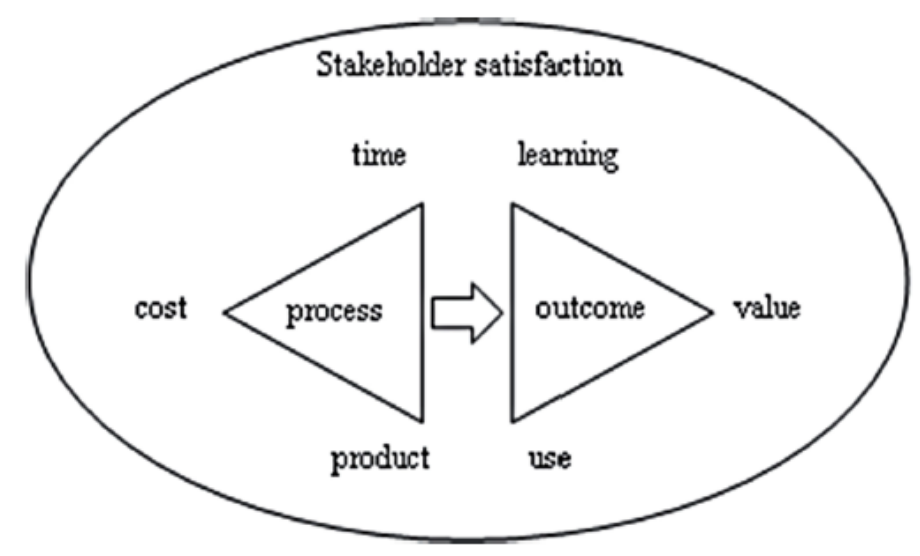

Figure 1. Project Success Criteria (Nelson, 2005)

Nelson (2005) also defines two new terms: "failed success" for a project with a successful process but unachieved outcome, and a "successful failure" for a failed process with achieved outcome.Shenhar et al (1997) suggests four success dimensions, namely: project efficiency (same as golden triangle), impact on the customer (same as product), business and direct success, and preparing for the future. Baccarini (1999) introduces a logical framework to define project success. He argues that four levels of project objectives should be considered for project success; goals, purpose, output and input.

Other authors provide full comprehensive models that include many of the previously discussed dimensions in literature. For example, El-Masri (2009) introduces Information 
System success model that constitutes of five perspectives. The first dimension represents the behavioral dimension that represents the project's process efficiency (process success); the second dimension is the technological aspect of Information Systems (IS) project success which measures the quality and functionality of the system (product success); the third one is the operational dimension that measures the operational benefits of system use; the fourth dimension is strategic and financial impact that measures business success achieved by the introduced system; finally, the fifth dimension measures the degree of stakeholder satisfaction process-wise and the outcome-wise.

Barclay (2008) also develops Project Performance Scorecard (PPS) frameworks that can help in assessing Information System project outcomes while learning from Information System project management practices. The framework combines six dimensions together; stakeholder, project process, quality, innovation and learning, benefit and use perspectives. The model introduces the question "why is the project important?" from different angles according to different stakeholders. The six perspectives are described below.

The Project Process perspective, considers the whole processes of the project till handing it over to determine the financial gains and the efficient use of time. The Stakeholder perspective considers and monitors the complex nature of the stakeholders. The Learning \& Innovation perspective focuses on the knowledge that can be acquired from the project. The Benefit perspective, considers the gains and business value that the project achieve. The Quality perspective relates to meeting or exceeding stated objectives of project process and outcome.

Howsawi\& Eager (2014) propose a systematic framework with four levels; Project process: (Project management process), Products and deliverables, Business (benefits and returns (or losses) of the project to the stakeholders), Context and externalities: (considers contextual circumstances and externalities that affect it). Although, the El-Masri (2009), Barclay (2008) and Howsawi\& Eager (2014) models are comprehensive enough to include nearly all of the thought aspects, they unfortunately are hard to be measured and unrealistic to be used especially with small projects that take short time to be accomplished. The mentioned assessments may need more time than the project development itself.Besides that, it has been recorded that Software projects assessment mainly varies with different and sometime contradictory stakeholders' perspectives. (Barclay, 2008), which may be impossible to reconcile between them.

A good summary for the previous models is provided in Mcleod et al (2012) work that expands the concept of project success to include more than the iron-triangle parameters as shown in table 1. Taking into consideration that in practice not all criteria elements may be applicable for all projects (Bannerman, 2008; Shenhar et al, 2001). Mcleod et al (2012) define the project success over the three periods of time; First period defines process success; second period defines product success; and the last stage defines project success impact on organization. 


\begin{tabular}{|c|c|c|}
\hline \multicolumn{3}{|l|}{ Expanding dimensions } \\
\hline Process Success & Product Success & Organizational Success \\
\hline Focus on project management & Focus on project objectives & Focus on organizational objectives \\
\hline - On time & - Product use & - Business benefits \\
\hline - Within budget & - Client satisfaction & - Strategic benefits \\
\hline - To scope/specifications & - Client benefits & \\
\hline
\end{tabular}

Figure 2. Success Measure Mcleod et al (2012)

The model also takes into consideration the fact that different elements of criteria are not clear enough on the short run, and these element can be evaluated only on different time frames, whereas Project management process success can be evaluated during project implementation; meanwhile product success can be evaluated immediately after product is being handed over. When the software is completed and handed over to be used, client satisfaction and benefit can be known consecutively. Eventually, organizational success can be identified if the organization gains business and strategic benefits at the final stage.

\section{The SbyO Model}

The previous discussed models in literature tried to provide a universal evaluationthat include all possible points of view in one model, and that made their models complex, time-consuming and unrealistic to apply El-Masri(2009), Barclay(2008) and Howsawi \& Eager (2014). However, provision for a universal set of criteria to be measured is very problematic Mcleod, et al (2012) due to the multifaceted and sometimes contradictory nature of stakeholders views (Davis,2013) .

This research presents SbyO model (Success by Objectives model) that sets the basis for different criteria of success measurement per project, and at the same time it is flexible to adapt with various clients and changing environment. The elements of the criteria isspecified based on project objectives and also on projects main stakeholders, which are both defined at project kick off.If the main objective, for example, of the project according to key stakeholders is operational, then the golden triangle must be valued more than other elements.Moreover, because objectives are variables, they can be anything relevant to the project, but as a place to start from, the author suggests to begin with the elements provided by Mcleod (2012): process success, product success and lastly project success impact on organization.

The SbyO model takes into account the importance (rank) of different stakeholders' views. As there are several stakeholders with several points of views, it's important to consider which elements to be included in the criteria and which ones to be ignored.This can be done by ranking stakeholders' importance (I) and then to multiply it (I) with the measure factor to evaluate its value according to stakeholder's importance as in table 1. Considering stakeholders' importance and changing objectives per project is the first contribution of this paper. Also, considering time validity for each criteria element is very important, because as McLeod et al (2012) cite that some elements are impossible to be evaluated before time passes on project deployment. Software (the product) affects the client and, consecutively, business gain needs time to be clarified. 


\section{Ml Macrothink}

Moreover, the time factor is rarely considered among other authors (Mcleod et al, 2012), but it is essential for SW industry. Our model considers the time factor as it is clarified in the table, whereas each element must be labeled when measuring: Short - Medium or Long term factor as in the time frame row. Time frame consideration is the other contribution of the paper. SbyO model is well represented using the SbyO a cross-table shown in table 1, and can be obtained by the following steps: 1. Identify Key Stakeholders (Sponsor, Top Management,....). 2. Identify their importance to project success (Provide weights - I) 3. Identify main project's objectives. Objectives are variable, and they can be anything related to the project, but to build on what is stated before, the author suggests to begin with factors provided by Mcleod (2012) on time, within budget, on specs, product use, client satisfaction, business benefit and strategic benefit. 4. Set the value for each objective importance according to each stakeholder view (F). 5. Multiply (I) by (F) to weight the value of each objective according to stakeholder importance. 6. calculate the summation for each objective (SWtime, SWCost,......). Elements with the highest Summation are mainly to be considered for measuring project success. These elements as described are specified according to projects' main objectives and according to stakeholders' importance to reflect projects diversity.

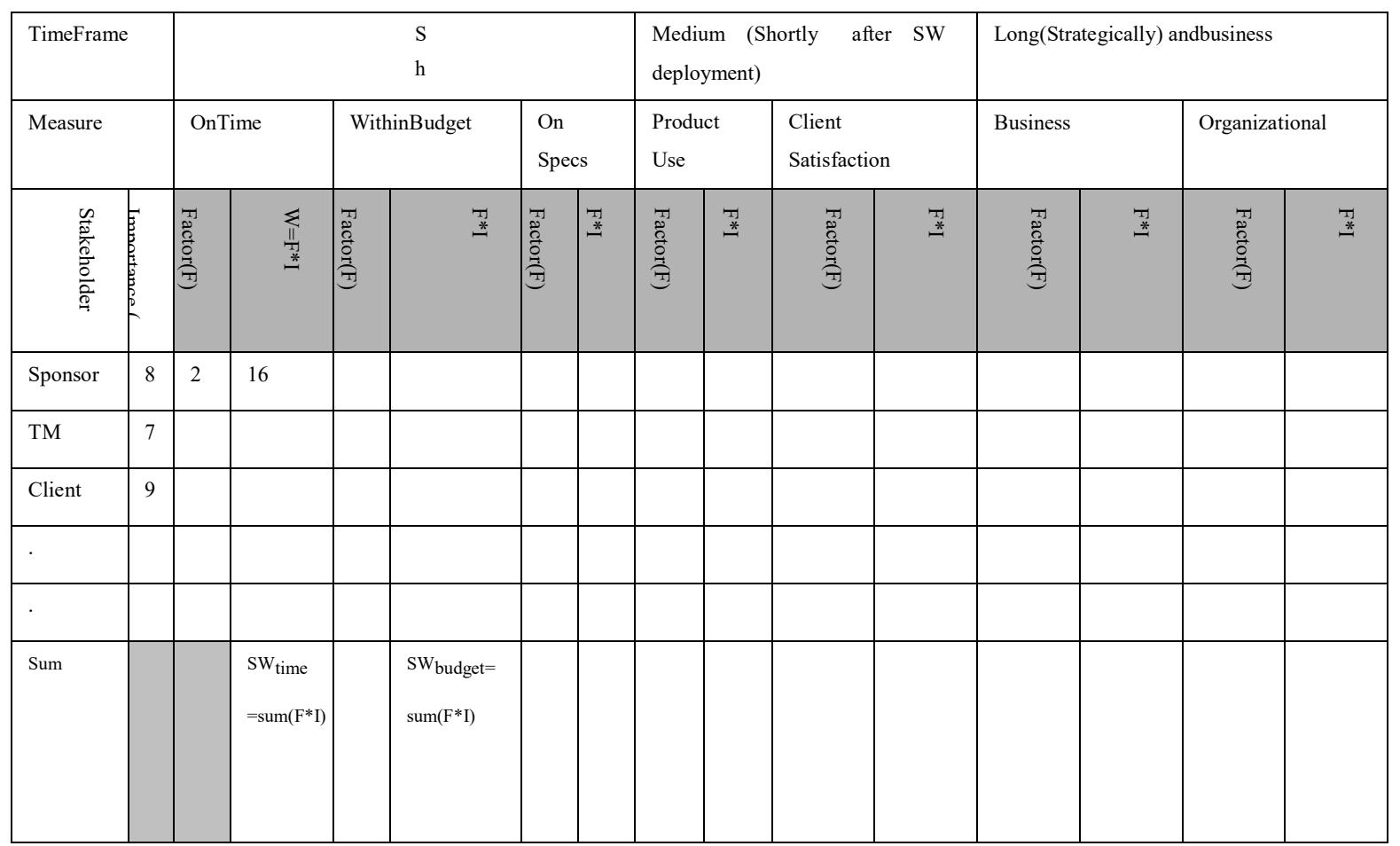

\section{Conclusion}

There have been little concerns in literature about the uniqueness of SW projects and their diversity. Universal criteria for all projects in general, and for all SW projects in particular is not possible. A flexible and variable criterion is essential to be used. Wrong perception to 
project success is very fundamental to set the stage for the whole project management and software engineering topics. We proposed a general Software success model primarily based on objectives are related to primary stakeholders. The model provides a crosstable that could be used to measure process success. The proposed model was evaluated and accepted by two project management experts.

\section{References}

Agarwal, N., \& Rathod, U. (2006). Defining 'success' for software projects: An exploratory revelation. International Journal of Project Management, 24(4), Pp.358-370. https://doi.org/10.1016/j.ijproman.2005.11.009

Alderman, N., \& Ivory, C. (2011). Translation and convergence in projects: An organizational perspective on project success. Project Management Journal, 42(5), 17-30. https://doi.org/10.1002/pmj.20261

Adomavicius G., Bockstedt , J. C, Gupta , A. \& Kauffman R.K(2008). Making sense of technology trends in the information technology landscape: a design science approach. MIS Quarterly, 32(4), 779-809. https://doi.org/10.2307/25148872

Baccarini, D. (1999). The Logical Framework Method for Defining Project Success. Project Management Journal, 30(4), 25-32.

Bhoola, V. (2015). Impact of Project Success Factors in Managing Software Projects in India: An Empirical Analysis. Business Perspectives \& Research, 3(2), 109-125. https://doi.org/10.1177/2278533715578555

Barclay, C. (2008). Towards an integrated measurement of IS project performance: The project performance scorecard. Information Systems Frontiers, 10(3), 331-345. https://doi.org/10.1007/s10796-008-9083-6

Barclay, C., \& Osei-Bryson, K.-M. (2009). Determining the Contribution of IS Projects: An Approach to Measure Performance. In Proceedings of the 42nd Annual Hawai'i International Conference on System Sciences, p. 1, Sprague, R.H., Piscataway.

Bannerman, P. L. (2008). Defining project success: A multilevel framework. In Proceedings of the PMI research conference (pp. 1-14). Newtown Square, PA: Project Management Institute.

Brooks FP. (1987). No silver bullet: Essence and accidents of software engineering. IEEE Computer, 20(4), 10-19. https://doi.org/10.1109/MC.1987.1663532

Chemuturi, M., \& Cagley, T. (2010). Mastering Software Project Management: Best Practices, Tools and Techniques J. Ross Publishing

Cuthbertson, R., Furseth, P. I., \& Ezell, S. J. (2015). Kodak and Xerox: How High Risk Aversion Kills Companies. In Innovating in a Service-Driven Economy (pp. 166-179). Palgrave Macmillan UK.

Dalcher, D. (2014). Rethinking Success in Software Projects: Looking Beyond the Failure 
Factors. In Software Project Management in a Changing World (pp. 27-49). Springer Berlin Heidelberg.

Davis, K. (2013). Different stakeholder groups and their perceptions of project success. International Journal of Project Management, 32(2), 189-201. https://doi.org/10.1016/j.ijproman.2013.02.006

De Carvalho, M. M., Patah, L. A., \& de Souza Bido, D. (2015). Project management and its effects on project success: Cross-country and cross-industry comparisons. International $\begin{array}{llll}\text { Journal of } \quad \text { Project } & \text { Management, } & \text { 33(7), }\end{array}$ https://doi.org/10.1016/j.ijproman.2015.04.004

Erling, S.A., David, B., Svein Arne, J., \& Arthur, H.M. (2006). Exploring project success. Baltic Journal of Management 1(2), 127. https://doi.org/10.1108/17465260610663854

El-Masri, M. (2009). A model of IS project success. In ASAC, 30(4).

Ghapanchi, A. H. (2015). Investigating the Interrelationships among Success Measures of Open Source Software Projects. Journal Of Organizational Computing \& Electronic Commerce, 25(1), 28-46. https://doi.org/10.1080/10919392.2015.990775

Handigund, S.M., \& Arunakumari, B.N. (2013). An ameliorated methodology for the identification of project activities of software development projects. Advances in Computing, Communications and Informatics (ICACCI), 2013 International Conference on pp.172, 177 https://doi.org/10.1109/ICACCI.2013.6637166

Howsawi, E., \& Eager, D.(2014), The four-level project success framework: application and assessment. Organisational Project Management 1(1) 1-15 https://doi.org/10.1108/17465260610663854

Ika, L. A. (2009). Project Success as a Topic in Project Management Journals. Project management Journal, 40(4), 6-19. https://doi.org/10.1002/pmj.20137

Jonkers, R., Rossum R. V., \& Silvius A.J. G. (2015) The Relationship between Information Systems Strategy and the Perception of Project Success. International Journal of Information Technology Project Management (IJITPM), $\quad 6(1), \quad$ 1-25. https://doi.org/10.4018/ijitpm.2015010101

Joosten, D. Basten D., \& Mellis, W. (2011). Measurement of information system project success in organizations-What researchers can learn from practice. Proceeding of ECIS'11, Paper 177, 2011.

K Jugdev., \& R Moller. (2006). A retrospective look at our evolving understanding of project success. IEEE Engineering Management Review, 34(3), 110-127 https://doi.org/10.1109/EMR.2006.261387

Kamhawi, M.E. (2007). Critical Factors for Implementation Success of ERP Systems: An Empirical Investigation from Bahrain. International Journal of Enterprise Information Systems, 3(2), 3449. https://doi.org/10.4018/jeis.2007040103 
Law, C.H.C., \& Ngai, W.T.E. (2007). ERP systems adoption: An exploratory study of the organizational factors and impacts of ERP success. Information \& Management, 44(4), 418-432. https://doi.org/10.1016/j.im.2007.03.004

Mcleod, L., Doolin, B., \& Macdonell, S. G. (2012). A Perspective-Based Understanding Of Project Success. Project Management Journal, 43, 68-86. https://doi.org/10.1002/pmj.21290

Mishra P., Dangayach, G. S., \& Mittal, M. L. (2011). An Empirical Study On Identification Of Critical Success Factors In Project Based Organizations. Global Business And Management Research: An International Journal, 3, 356-368

Mitchell, L.V. (2006). Knowledge Integration and Information Technology Project Performance. MIS Quarterly, 30(4), 919-939. https://doi.org/10.2307/25148759

Mlot, S. (2013). Infographic: Reader Joins Graveyard of Failed Google Projects. PC. Retrieved from http://www.pcmag.com/article2/0,2817,2421182,00.asp

Nethathe, J. M., Van Waveren, C. C., \& Chan, K. Y. (2011). Extended critical success factor model for management of multiple projects: An empir ical view from Transnet in South Africa. South African Journal Of Industrial Engineering, 22(2), 189-203. https://doi.org/10.7166/22-2-25

Nelson, R. (2005). Project Retrospectives: Evaluating Project Success, Failure, and Everything in Between. MIS Quarterly Executive, 4(3), 361-372.

Nelson, R. Ryan. (2007). IT project management: Infamous failures, classic mistakes, and best practices. MIS Quarterly Executive, 6(2), 67-78.

Nilsson, J. (2009). Segmenting socially responsible mutual fund investors: The influence of financial return and social responsibility. International Journal of Bank Marketing 27(1), 5-31. https://doi.org/10.1108/02652320910928218

Ojiako, U., Johansen, E., \& Greenwood, D. (2008). A qualitative re-construction of project measurement criteria. Industrial Management + Data Systems, 108(3), 405-417. https://doi.org/10.1108/02635570810858796

Pan, G., Hackney, R., \& Pan, L.S. (2008). Information Systems implementation failure: Insights from prism. International Journal of Information Management, 28(4), 259-269. https://doi.org/10.1016/j.ijinfomgt.2007.07.001

Pinto, J. K., \& Slevin, D. P. (1988). Project success: Definitions and measurement techniques. Project Management Journal, 19(1), 67-72.

PMI. (2013). A guide to the project management body of knowledge (PMBOK guide). Fifth edition Newtown Square, Pa.

Ruhe, G. \& Pfahl, D. (2015). Introduction to Analytical Software Project Management Minitrack. System Sciences (HICSS), 2015 48th Hawaii International Conference. pp.5143, 5143. https://doi.org/10.1109/HICSS.2015.663 
Ruhe G., \& Wohlin C. (2014) Software Project Management in a Changing World1st edition. Springer Sauer, C., Gemino, A. and Reich, B.H. (2007) The Impact of Size and Volatility in IT Project Performance. Communications of the ACM, 50(11), 79-84.

Schwalbe, K. (2016). Information technology project management. Cengage Learning, Boston, MA

Shrnhur, A. J., Levy, O., \& Dvir, D. (1997). Mapping the dimensions of project success. Project management journal, 28(2), 5-13.

Thomas, G., \& Fernández, W. (2008). Success in IT projects: a matter of definition. International Journal of Project Management, 26(7), 733-742. https://doi.org/10.1016/j.ijproman.2008.06.003

Wang, T.G.E., Shih, S.-P., Jiang, J.J., \& Klein, G. (2006). The relative influence of management control and user-IS personnel interaction on project performance. Information and Software Technology, 48(3), 214-220. https://doi.org/10.1016/j.infsof.2005.04.003

Westhuizen, D., \& Fitzgerald, E. P. (2005). Defining And Measuring Project Success. European Conference On IS Management, Leadership And Governance

Wiener, M. (2006). Critical Success Factors of Offshore Software Development Projects: The Perspective of German-Speaking Companies. 1st Edition. Deutscher Universitätsverlag. https://doi.org/10.1007/978-3-8350-9333-1 